EGU2020-4507

https://doi.org/10.5194/egusphere-egu2020-4507

EGU General Assembly 2020

(c) Author(s) 2021. This work is distributed under

the Creative Commons Attribution 4.0 License.

\title{
A wireless system for volumetric water content measurement by TDR
}

Antonio Villoro ${ }^{1}$, Borja Latorre ${ }^{1}$, Juanjosé Jiménez ${ }^{2}$, María Victoria López ${ }^{1}$, José Manuel Nicolau ${ }^{3}$, Jaume Tormo ${ }^{3}$, and David Moret-Fernández ${ }^{1}$

'ESTACIÓN EXPERIMENTAL DE AULA DEI, CONSEJO SUPERIOR DE INVESTIGACIONES CIENTÍFICAS (CSIC), ZARAGOZA, Spain (david@eead.csic.es)

${ }^{2}$ INSTITUTO PIRENAICO DE ECOLOGÍA, CONSEJO SUPERIOR DE INVESTIGACIONES CIENTÍFICAS (CSIC), JACA, Spain

${ }^{3}$ ESCUELA POLITÉCNICA SUPERIOR (IUCA) UNIVERSIDAD DE ZARAGOZA, HUESCA, SPAIN.

Time Domain Reflectometry (TDR) is an accurate and widely used technique for real time estimation of soil volumetric water content $(\theta)$, and the bulk electrical conductivity $(\sigma)$. Although there are multiple software that allow monitoring $\theta$ and $\sigma$ by connecting the TDR device to a PC, this system used under field conditions can be in many cases awkward. This paper presents a wireless, portable, unexpansive, simple, and versatile system to measure $\theta$ and the $\sigma$ by connecting the TDR device to a smart phone. The system consists on a M5Stack processing unit that integrates a Wifi connectivity. The UART port of the M5Stack is connected to the TDR device through RS232-ttl adapter. The hardware is programmed in micropython language that allows the M5Stack acts as a server between the user and the TDR device through a web page read with a smart phone. The software, which is compatible with Campbell TDR100 and 1502C Tektronix devices, allows creating different project where the TDR waveforms are stored. A simple $\theta$ and the $\sigma$ measurement is also allowed. Since the objective of the portable system is to ease and makes $\theta$ and $\sigma$ samplings faster, a complementary web page for subsequent and more accurate estimates of $\theta$ and $\sigma$ was also developed. 